\title{
The opinion of patients with inflammatory bowel disease on healthcare received
}

\author{
F. Casellas, G. Fontanet, N. Borruel and J. R. Malagelada \\ Service of Digestive Diseases. Unitat d'Atenció Crohn-Colitis (UACC). Hospital Universitari Vall d'Hebron. Barcelona, \\ Spain
}

\begin{abstract}
Background: an item to consider in analyzing a healthcare model for a population group suffering from chronic disease is necessary health-care resources, their use, and their rating by endusers. Regarding inflammatory bowel disease (IBD), healthcare resources used by patients are numerous and varied, and yet they have been never assessed.
\end{abstract}

Design: an anonymous self-rated questionnaire has been developed with 24 basic questions on overall disease, who is monitoring the patient, how are visits scheduled, need for urgent care, patient view on how control may be improved, etc. This questionnaire was sent to 393 patients who were asked to fill it out and then return it by mail.

Results: two hundred and thirty-seven patients returned a filled-out questionnaire. Most patients were followed up in a hospital, and only $8.8 \%$ were being monitored by a general practitioner or area specialist. Ninety-two percent of patients reported visits were routinely scheduled irrespective of clinical status, and $79.6 \%$ of patients reported having occasionally presented to an emergency department, because of not knowing what to do or due to having no other resources available in $25.2 \%$ of times. This entails that $38 \%$ of visits to an emergency unit may be prevented with a better understanding of disease or by means of a phone call. Thirty percent of patients reported that current healthcare is inadequate in terms of contents, form, or waiting time. In all, $97.8 \%$ of patients feel that information and knowledge on their disease would help in its control, and $69.6 \%$ consider that adequate information would allow them to initiate a proper treatment before visiting their doctor. Family care is another poorly lookedafter aspect that $74.6 \%$ of subjects believe would be of help in controlling their disease.

Conclusions: overall, the opinion of patients with IBD on healthcare received is good; however, a number of deficiencies were detected, as is the case with insufficient information, care of family members, and healthcare resources accessibility/agility.

Recibido: 18-09-03.

Aceptado: 07-10-03.

Correspondencia: Francesc Casellas. Servei de Digestiu. Hospital Universitari Vall d'Hebron. Pso. Vall d'Hebron, 119. 08035 Barcelona. Fax: 93 48944 56.e-mail: fcasellas@vhebron.net
Key words: Health care. Information resources. Inflammatory bowel disease. Ulcerative colitis. Crohn's disease.

Casellas F, Fontanet G, Borruel N, Malagelada JR. The opinion of patients with inflammatory bowel disease on healthcare received. Rev Esp Enferm Dig 2004; 96: 174-184.

\section{INTRODUCTION}

A major goal of inflammatory bowel disease (IBD) management is to improve patient health-related quality of life (HRQoL) regardless of the type of therapy used (1). This improves well-being for both patients (2) and household members (3), and reduces sanitary expense (4). Many factors are involved in HRQoL perception; some are directly related to IBD (5), and some are not. Quality of healthcare received stands out amongst the latter in such a way that improved healthcare favors improved HRQoL (6). Therefore, the quality of healthcare received by patients with IBD should be as high as possible, and it should also fulfil the healthcare needs of the population. In this sense, healthcare programs such as the Pla de Salut de Catalunya envisage to preferentially assess user views and expectations on the efficiency and quality of services and healthcare processes (7).

Healthcare resources used by patients with IBD are numerous and varied, since they include medical visits, hospitalization, examinations, surgical procedures, medication expenses, etc. Studies performed in the United States have estimated a mean expense per patient with Crohn's disease per year of 12,417 U.S. dollars (8), with a yearly expense above one thousand million 1990 dollars in that country (9). Crohn's disease has been estim- 
ated to generate a total expense of 43.1 million 1994 dollars in Sweden (10). These data give an idea of the financial burden IBD represents for society. However, user use and rating of resources available for IBD patients are poorly understood in our country. Our goal was to establish the use and adequacy of healthcare resources for patients with IBD, and to detect other resources that may be potentially needed. To this end, a study in the form of a cross-sectional opinion poll was carried out, where an anonynous self-report survey was mailed to patients in order to know their opinion on the quality and adequacy of the medical resources they use.

\section{METHODS}

\section{Patients}

A survey was mailed to 393 patients diagnosed with ulcerative colitis or Crohn's disease who had enrolled in Unitat d'Atenció Crohn-Colitis (UACC), irrespective of main complaint and follow-up center. All patients who returned a correctly filled-out questionnaire have been included.

\section{Method}

The survey was mailed to the homes of all participants. Enclosed was a self-addressed stamped envelope for the returning of the filled-in questionnaire to UACC. The survey was anonymous and made up of 24 basic questions on patient social and demographic data, overall disease, controlling staff, how visits were scheduled, need for urgent care, rating of healthcare received, view on how control may be improved, suggestions for improved healthcare, etc.

\section{Statistical analysis}

When results obtained failed to pass the KolmogorovSmirnov normality test, the results of quantitative variables were expressed as median and 25-75 percentiles. Differences between median values were estimated by using the Mann-Whitney test. Differences between proportions were established by using Fisher's test. P values below 0.05 were accepted as significant.

\section{RESULTS}

\section{Patients}

Of 393 patients surveyed, $237(60.3 \%)$ returned a correctly filled-out questionnaire; 115 of these were patients with Crohn's disease and 122 were patients with ulcerative colitis. Major characteristics of patients included are listed in tables I and II. Age was similar in both
Table I. Major characteristics of patients included. Results are expressed as median values ( 25 percentile-75 percentile)

\begin{tabular}{lcc}
\hline & Crohn's disease & Ulcerative colitis \\
\hline Number & 115 & 122 \\
Age & $32(24-42)$ & $37(31-52)$ \\
Gender (M/F) & $52 / 63$ & $58 / 64$ \\
Population & & \\
$\quad<100.000$ inhab. & $34 \%$ & $30 \%$ \\
$100.000-500.000$ inhab. & $17 \%$ & $12 \%$ \\
$\quad$ > 500.000 inhab. & $49 \%$ & $57 \%$ \\
Family status & & \\
Single & $39 \%$ & $28 \%$ \\
Married & $55 \%$ & $66 \%$ \\
$\quad$ Widowed & $1 \%$ & $1,5 \%$ \\
$\quad$ Separated & $5 \%$ & $4,5 \%$ \\
Education level & & \\
$\quad$ No education & $1 \%$ & $6 \%$ \\
Primary education & $28 \%$ & $37 \%$ \\
Secondary education & $42 \%$ & $34 \%$ \\
$\quad$ University degree & $29 \%$ & $23 \%$ \\
Occupational status & & \\
Employed - self employed & $55 \%$ & $54 \%$ \\
Retired - pensioner & $13 \%$ & $12 \%$ \\
Housewife & $9 \%$ & $19 \%$ \\
Student & $14 \%$ & $7 \%$ \\
Unemployed & $6 \%$ & $7 \%$ \\
Other & $3 \%$ & $1 \%$ \\
\hline
\end{tabular}

Table II. Major characteristics of underlying disease for patients included. Results are expressed as median values (25 percentile-75 percentile)

\begin{tabular}{lcc}
\hline & Crohn's disease & Ulcerative colitis \\
\hline Number & 115 & 122 \\
Evolution time (years) & $5(2-10)$ & $5(2-9)$ \\
History of hospitalizations & $81.8 \%$ & $57.3 \% *$ \\
Number of hospitalizations & $2(1-4)$ & $1(0-2)^{*}$ \\
History of surgical procedures & $46.1 \%$ & $13.2^{*}$ \\
\hline
\end{tabular}

* $=p<0.05$.

Crohn's disease and ulcerative colitis groups of patients, and a slight predominance of females was seen in both groups. As expected, most patients in both groups lived in a big city. Family status was also similar for both group of patients, with married patients predominating followed by single patients. Also, education level was similar for both groups of patients. Most had primary or secondary education, and approximately $25 \%$ of patients had a university degree. Most patients in both groups were occupationally active, either for third parties or through self-employment. Six percent of patients with Crohn's disease and $7 \%$ of patients with ulcerative colitis were unemployed, but the number of cases in which this was due to their disease remains unknown. 


\section{Healthcare received}

Ninety-four percent of patients with Crohn's disease and $89 \%$ of patients with ulcerative colitis were medically followed by a hospital gastroenterologist, whereas only 3 and $8 \%$ were followed by a primary care center gastroenterologist, respectively, and $3 \%$ in both groups reported being followed by their general practitioner. The high number of patients controlled in a hospital is likely a bias due to the fact that patient recruitment took place in a tertiary referral hospital.

For both Crohn's disease $(93.1 \%)$ and ulcerative colitis $(90.9 \%)$ patients, most visits were scheduled in the previous one regardless of disease activity. Only $6.1 \%$ of patients with Crohn's disease and $8.2 \%$ of patients with ulcerative colitis were appointed when symptoms arose.

The need for urgent visits is a difficulty commonly experienced by patients with IBD, as they require treatment updates when flare-ups or complications arise. Even though most visits are routinely scheduled on the previous appointment, the fact that treatment changes occur with minor delays in $75 \%$ of cases is conspicuous, and may be due to phone consultations by the patients, urgent visit rescheduling or self-medication (Table III). When asked "how many days usually elapse from the time you start to feel worse to the time your doctor prescribes you a therapy?", patients surprisingly report a median of merely $1(0-3.5)$ day for Crohn's disease and $1(0-5)$ day for ulcerative colitis.

Table III. Delays in treatment changes when an urgent situation arises

\begin{tabular}{lcc}
\hline & Crohn's disease & Ulcerative colitis \\
\hline No delay, phone consultation & $50 \%$ & $39 \%$ \\
No delay, fast scheduling & $20 \%$ & $25 \%$ \\
No delay, self-medication & $8 \%$ & $11 \%$ \\
Delayed scheduling & $10 \%$ & $11 \%$ \\
Don't know, no answer & $12 \%$ & $14 \%$ \\
\hline
\end{tabular}

A significant number of patients with IBD has to visit a hospital's emergency department sometime. In fact, $85 \%$ of patients with Crohn's disease and $75 \%$ of patients with ulcerative colitis had at least once been to an emergency department ( $p=$ NS between these two groups of patients). Reasons alleged by patients for their presenting to emergency care are listed in table IV. Patients were asked whether in their own view their visits to emergency departments could have been prevented. Most patients (62\% of those with Crohn's disease and $61 \%$ of those with ulcerative colitis) considered that their visits to emergency departments could not have been avoided. However, $20 \%$ of patients in the Crohn's disease group and $21 \%$ of those in the ulcerative colitis group reported that their visit to an emergency department could have
Table IV. Reasons to present to hospital emergency departments

\begin{tabular}{lcc}
\hline & Crohn's disease & Ulcerative colitis \\
\hline Flare-up severity & $62 \%$ & $48 \%$ \\
Not knowing what to do & $14 \%$ & $19 \%$ \\
Having no other option & $9 \%$ & $8 \%$ \\
Never needed emergency care & $15 \%$ & $25 \%$ \\
\hline
\end{tabular}

been prevented, should they have had more information and greater self-monitoring skills. In this same sense, $18 \%$ of patients with Crohn's disease or ulcerative colitis considered they might have skipped their visit to an emergency department if they had had a telephone clinic available.

Results obtained for the question "Do you think current healthcare is adequate to control your disease?" are listed in table V. It must be pointed out that most patients in both groups reported that the current healthcare system was adequately meeting their needs. Anyway, a valuable number of patients considered that delays in medical care were excessive, and a smaller number of patients deemed healthcare type inadequate (Table V).

Table V. Patient consideration of the adequacy of healthcare

\begin{tabular}{lcc}
\hline & Crohn's disease & Ulcerative colitis \\
\hline It perfectly covers my needs & $66 \%$ & $64 \%$ \\
Poor contents & $7 \%$ & $11 \%$ \\
Poor waiting times & $17 \%$ & $15 \%$ \\
Poor care, and delays & $4 \%$ & $6 \%$ \\
Don't know, no answer & $6 \%$ & $4 \%$ \\
\hline
\end{tabular}

An aspect that was to be established was whether patients considered that care to their immediate environment, e. g. their family members, was necessary for the control of their disease. Fifty-two patients $(46 \%)$ in the Crohn's disease group and 43 patients $(36 \%)$ in the ulcerative colitis group answered that care to their family environment was highly necessary to help control their disease. Only 20 patients in the Crohn's disease group $(17 \%)$ and 36 patients in the ulcerative colitis group $(30 \%)$ considered that care to their family environment was of no help in controlling their disease. The difference in the proportion of patients who did not consider family care a need was statistically significant between the Crohn's disease and the ulcerative colitis groups $(\mathrm{p}<0.05)$.

\section{Information on IBD}

Patients were asked whether they considered information and knowledge on their disease as a relevant item for 
the control of their health. Results are listed in table VI, which shows that virtually all patients considered having adequate information significant. These data are in contrast with the fact that nearly one half of patients considered they had adequate information but still many doubts, and that $13 \%$ of those in the Crohn's disease group and $16 \%$ of patients in the ulcerative colitis group considered they had not adequate information (Table VI). Patients were asked whether they considered that they could initiate treatment before getting in touch with their doctor in case of having adequate information, in order to start medication as soon as possible for flare-up symptoms, and most patients in both groups gave an affirmative response (Table VI).

Table VI. Patients' consideration of the role of diseaserelated information and knowledge in the control of IBD

\begin{tabular}{lcc}
\hline & Crohn's disease & Ulcerative colitis \\
\hline Do you considerer it important & & \\
having enough information & & \\
on your disease? & & \\
Yes, it is very important & $84 \%$ & $78 \%$ \\
Yes, that'd help control my disease & $14 \%$ & $19 \%$ \\
No, not specially & $1 \%$ & $1 \%$ \\
Don't know, no answer & $1 \%$ & $2 \%$ \\
& & \\
Do you consider you have & & $39 \%$ \\
enough information? & $37 \%$ & $44 \%$ \\
Yes, I do & $49 \%$ & $16 \%$ \\
Yes, but I have many doubts & $13 \%$ & $1 \%$ \\
No, not enough & $1 \%$ & \\
Don't know, no answer & & \\
& & \\
If you had enough information; & & \\
would you start treating a & & \\
flare-up before consulting? & & \\
Yes & $63 \%$ & \\
No & $36 \%$ & \\
Don't know, no answer & $1 \%$ & \\
\hline
\end{tabular}

Aspects on which patients considered themselves poorly informed were analyzed, and only 7 patients $(6 \%)$ in the Crohn's disease group and 8 patients $(6 \%)$ in the ulcerative colitis group highlighted none of the available choices, suggesting that there was no area of interest on which they deemed more information necessary regarding their disease. However, most patients considered that more information was needed in more than just one area of interest, which they ticked accordingly (Table VII).

\section{Suggestions to improve healthcare}

In the questionnaire that was mailed to the patients a blank space was provided for their jotting down suggestions that in their view might contribute to healthcare im-
Table VII. Number of patients who ticked aspects of IBD which they considered they lacked enough information about. Most patients ticked more than one area of interest

\begin{tabular}{lcc}
\hline & Crohn's disease & Ulcerative colitis \\
\hline Causes of disease & 65 & 80 \\
Potential outcome of disease & 60 & 62 \\
Complications that may arise & 58 & 67 \\
Management of disease & 24 & 24 \\
Need for surgical procedure & 19 & 25 \\
Possibility of transmission to & & \\
$\quad$ offspring or contagion & 36 & 22 \\
\hline
\end{tabular}

provement. Suggestions may be summarized as follows: provision of more information, faster scheduling of visits and examinations, improved accessibility to services, design of psychological help programs, availability of diets and dieticians, setup of integrated care units, more thoroughly informed physicians, support for medical research on the disease, and sensitization of society to IBD.

\section{DISCUSSION}

Identifying the healthcare-related needs and views of patients with chronic disease may help rationalize resources and improve care. This is the reason why a survey was mailed to 393 patients with imflammatory bowel disease. Patients were recruited from the records of Unitat d'Atenció Crohn-Colitis in a attempt to obtain patient characteristics with as much variation as possible. Thus, both patients with Crohn's disease and ulcerative colitis, males and females, etc., were included. Time elapsed since diagnosis was 5 years, more than one half of patients needed hospitalization sometime, and $46.1 \%$ of patients with Crohn's disease and $13.2 \%$ of patients with ulcerative colitis even required a surgical procedure. This reflects disease severity and the fact that patients have ultimately experienced all sorts of healthcare resources. However, against the representativeness of the chosen sample stands the fact that most patients were followed by specialized physicians in third-level hospitals. This suggests a possible bias in sample selection, and the sample would then include fewer patients with less agressive disease who were exclusively followed in primary care centers.

Most patients routinely schedule their visits during the previous one. This system of fixed periodical visits may be disadvantageous in that it may not meet patient needs when an emergency arises because of a flare-up, complications, etc. Notwithstanding, two thirds of surveyed patients reported no delays in medication changes as a result of phone consultations with their doctors, fast rescheduling or simply self-medication. This result is possibly biased, since phone consultations may be easier for patients included as a result of their keeping in touch 
with UACC, which facilitates and promotes this type of care. Anyway, there is currently a trend to replace fixed schedules with phone "as-needed" schedules, which is preferred by patients even though an agile healthcare system able to adapt itself to urgent needs is required $(11,12)$.

When a health-related difficulty arises that cannot be solved in offices and surgeries, patients present to hospital emergency rooms. This is not uncommon, since $85 \%$ of patients with Crohn's disease and $75 \%$ of patients with ulcerative colitis reported having presented to a hospital emergency room on occasion. Notions suggested by patients to presumably prevent it stand out simply as much as their extensive use of emergency care. Thus, about $20 \%$ of patients reported that they might not present to an emergency room if provided with more information, better self-control capabilities, or a telephone clinics service. This view supports the current trend to set up interactive monographic units such as UACC, in which phone consultations permit ongoing care that is tailored to each patient, with a reduced number of visits in person (13).

Overall, most patients reported being satisfied with the kind of healthcare they receive. However, aspects such as delays in appointments or care to the patient's closest environment, including the patient's family, should be improved. In this respect, inflammatory bowel disease has an impact beyond the patient him- or herself, and also involves household family members, which has an influence on family dynamics and affects relatives' quality of life (3).

Patients attach a lot of importance to being well informed, and a significant number amongst them consider their information inadequate. Multiple media to deliver information to patients and their families exist, which range from in-the-flesh deliveries to deliveries by phone, the internet, handouts, leaflets, video, magazines, books, associations, etc. Informing patients is important, at least because patients who perceive their information is poor report poorer quality of life (14), and acquiring knowledge on their disease is related to a better emotional adjustment to living with inflammatory bowel disease (15). Anyhow, information must be carefully delivered to patients, since recent observations suggest that handing out information leaflets to outpatients may slightly impair quality of life for a few days (16). However, when asked about the usefulness of receiving information leaflets, all patients considered them useful, even though information makes one third of patients more anxious (17). Anyway, the anxiety induced in patients with Crohn's disease by their accessing information through leaflet reading decreases in the long run (18). Most probably, the best system to convey information to patients is by verbal means in a person-to-person encounter, and this information may then be completed or deepened by using other modalities. Which may be more effective is as yet not well established. When compared, the effectiveness of knowledge acquisition on colonoscopy and cancer risk in patients with ulcerative colitis is the same for leaflets and leaflets plus videos (19). Nevertheless, knowledge (information) communication should be supplemented by appropriate information use (education) in order to acquire healthy living habits (health promotion).

An increasingly important information source is the internet. A recent survey of 173 patients from Asociación Catalana de Enfermos de Crohn y Colitis (ACCU) revealed that $84 \%$ of patients would be interested in visiting a web page on inflammatory bowel disease, and that $44 \%$ of patients searched the internet for topics related to their disease (20). Such evidence suggests that patients with inflammatory bowel disease are prone to acquiring information and willing to resort to cutting-edge resources to do so.

To conclude, patients with inflammatory bowel disease view healthcare received in an overall satisfactory manner. However, deficiencies such as inadequate information, lack of family care, and poor accessibility to available healthcare resources were detected. The setting up of interactive monographic units and novel telematic technologies will make up an essential resource for the improvement of care to patients with inflammatory bowel disease.

\section{REFERENCES}

1. Casellas F, López Vivancos J, Badia X, Vilaseca J, Malagelada JR. Impact of surgery for Crohn's disease on health-related quality of life. Am J Gastroenterol 2000; 95: 177-82.

2. Hörnquist JO. Quality of life: concept and assessment. Scand J Soc Med 1989; 18: 68-79.

3. Vergara M, Casellas F, Badia X, Malagelada JR. Assessing the quality of life of household members of patients with inflammatory bowel disease: development and validation of a specific questionnaire. Am J Gastroenterol 2002; 97: 1429-37.

4. De Boer A, Sprangers M, Bartelsman J, de Haes H. Predictors of health care utilization in patients with inflammatory bowel disease: a longitudinal study. Eur J Gastroenterol Hepatol 1998; 10: 783-9.

5. Casellas F, López-Vivancos J, Casado A, Malagelada JR. Factors affecting health related quality of life of patients with inflammatory bowel disease. Qual Life Res 2002; 11: 775-81.

6. Van der Eijk I, Stockbrügger R, Russel M. Influence of quality of care on quality of life in inflammatory bowel disease: literature review and studies planned. Eur J Int Medicine 2000; 11: 228-34.

7. Satisfacció dels usuaris dels serveis i participació dels ciutadans. En: Pla de Salut de Catalunya, 1999-2001. Generalitat de Catalunya, Departament de Sanitat i Seguretat Social. Primera edició, 1999. p. 171.

8. Feagan BG, Vreeland MG, Larson LR, Bala MV. Anual cost of care for Crohn's disease: a payor perspective. Am J Gastroenterol 2000; 95: 1955-60.

9. Hay JW, Hay AR. Inflammatory bowel disease: cost-of-illness. J Clin Gastroenterol 1992; 14: 309-17.

10. Ekbom A, Blomqvist P. Costs to society in Crohn's disease. Res Clin Forums 1997; 20: 33-9.

11. Williams JG, Cheung WY, Russell IT, Cohen DR, Longo M, Lervy B. Open access follow up for inflammatory bowel disease: pragmatic randomised trial and cost effectiveness study. Br Med J 2000; 320: 544-8.

12. Robinson A, Thompson DG, Wilkin D, Roberts C. Guided self-management and patient-directed follow-up of ulcerative colitis: a randomised trial. Lancet 2001; 358: 976-81. 
13. Miller L, Caton S, Lynch D. Telephone clinic improves quality of follow-up care for chronic bowel disease. Nurs Times 2002; 98: 36-8.

14. Moser G, Tillinger W, Sachs G. Disease-related worries and concerns: a study on out-patients with inflammatory bowel disease. Eur J Gastroenterol Hepatol 1995; 7: 853-8.

15. Olbrisch ME, Ziegler SW. Psychological adjustement to inflammatory bowel disease: informational control and private self-conciousness. J Chronic Dis 1982; 35: 573-80.

16. Borgaonkar MR, Townson G, Donnelly M, Irvine J. Providing disease-related information worsens health-related quality of life in inflammatory bowel disease. Inflam Bowel Dis 2002; 8: 264-9.

17. Connroy SP, Mayberry JF. patient information booklets for asian pa- tients with ulcerative colitis. Public Health 2001; 115: 418-20.

18. Smart H, Mayberry J, Calcraft B, Morris JS, Rhodes J. Effect of information booklet on patients' anxiety levels and consultation rates in Crohn's disease. Public Health 1986; 100: 184-6.

19. Eaden J, Abrams k, Shears J, Mayberry J. Randomized controlled trial comparing the efficacy of a video and information leaflet versus information leaflet alone on patient knowledge about surveillance and cancer risk in ulcerative colitis. Inflam Bowel Dis 2002; 8: 407-12.

20. Panés J, Lacy AM, Sans M, Soriano A, Piqué JM. Elevado índice de consultas por internet de los pacientes catalanes con enfermedad inflamatoria intestinal. Gastroenterol Hepatol 2001; 25: 306-9.

\title{
Opinión de los pacientes con enfermedad inflamatoria intestinal sobre la atención sanitaria recibida
}

\author{
F. Casellas, G. Fontanet, N. Borruel y J. R. Malagelada
}

Servicio de Aparato Digestivo. Unitat d'Atenció Crohn-Colitis (UACC). Hospital Universitari Vall d'Hebron. Barcelona

\section{RESUMEN}

Fundamento: un elemento a tener en cuenta al analizar un modelo de atención sanitaria dirigido a un grupo de población afecta de una enfermedad crónica es el de los recursos sanitarios necesarios, su utilización y la valoración que tienen los usuarios de ellos. En la enfermedad inflamatoria intestinal (EII) los recursos sanitarios utilizados por los enfermos son numerosos y variados, pero no han sido evaluados.

Diseño: se ha realizado una encuesta autorrellenable anónima de 24 preguntas básicas a cerca de datos generales de la enfermedad, quién les controla, cómo se programan las visitas, necesidad de atención urgente, cómo creen que se puede mejorar su control, etc. La encuesta se remitió al domicilio de 393 pacientes para su contestación y se les pidió que la devolvieran por correo.

Resultados: doscientos treinta y siete pacientes devolvieron la encuesta cumplimentada. La mayoría de los pacientes eran controlados en un hospital, y sólo el 8,8\% lo eran por el médico de cabecera o especialista de zona. El 92\% de pacientes refieren que las visitas se programan de forma rutinaria, independientemente del estado clínico. El 79,6\% de pacientes refiere haber acudido alguna vez a urgencias, siendo el motivo en el 25,2\% de las ocasiones no saber qué hacer o no tener otro recurso disponible. Ello explica que el 38\% de visitas al servicio de urgencias se podrían haber evitado con un mejor conocimiento de la enfermedad o una consulta telefónica. El 30\% de pacientes refiere que la actual atención sanitaria es inadecuada, ya sea por su contenido, la forma o el tiempo de espera. El 97,8\% de pacientes cree que la información y conocimiento de la enfermedad ayudarían a su control, de forma que el 69,6\% considera que con la información adecuada podrían iniciar el tratamiento ya antes de la visita médica. Otro aspecto poco atendido, y que el $74,6 \%$ de pacientes opina que ayudaría al control de la enfermedad, es la atención a su entorno familiar.

Conclusiones: la opinión general de los pacientes con EII sobre la atención sanitaria recibida es, en general buena, sin embargo se detectan carencias como la información insuficiente, el cuidado al entorno familiar y la accesibilidad-agilidad de los recursos sanitarios.

Palabras clave: Atención sanitaria. Recursos sanitarios. Enfermedad inflamatoria intestinal. Colitis ulcerosa. Enfermedad de Crohn.

\section{INTRODUCCIÓN}

Uno de los objetivos fundamentales del tratamiento de la enfermedad inflamatoria intestinal (EII), independientemente del tipo de terapéutica empleada, es mejorar la calidad de vida relacionada con la salud (CVRS) de los pacientes (1). Con ello se logra mejorar el bienestar tanto de los propios pacientes (2) como la de los familiares que conviven con ellos (3), y reducir el gasto sanitario (4). Muchos factores están implicados en la percepción de la CVRS, unos directamente relacionados con la EII (5) y otros externos a ella. Entre estos últimos destaca la cali- 
dad de la atención recibida, de forma que una mejor atención sanitaria favorece una mejor CVRS (6). Por ello, entre otras razones, es importante prestar a los pacientes con EII una atención sanitaria de la mejor calidad posible, que responda además a las de necesidades de salud de la población. En este sentido, los programas sanitarios, como el Pla de Salut de Catalunya, contempla ya entre sus líneas prioritarias de evaluación la opinión y expectativas de los usuarios sobre la eficiencia y calidad de los servicios y del proceso asistencial (7).

Los recursos sanitarios utilizados por los enfermos con EII son numerosos y variados, al incluir visitas médicas, hospitalizaciones, exploraciones, intervenciones quirúrgicas, gastos de medicación, etc. Estudios en Estados Unidos han contabilizado un gasto medio por enfermo de Crohn y año de 12.417 dólares (8) con un gasto anual para Estados Unidos superior a mil millones de dólares de 1990 (9). En Suecia se ha calculado que la enfermedad de Crohn genera un gasto total para el país de 43,1 millones de dólares de 1994 (10). Estos datos dan una idea de la carga económica que conlleva la EII para la sociedad. Sin embargo, en nuestro país no conocemos bien la utilización de recursos generada por la EII y la valoración que tienen los usuarios de los mismos. Nuestro objetivo ha sido determinar la utilización y adecuación de los recursos sanitarios usados por los pacientes con EII y detectar aquellos otros potencialmente necesarios. Para ello se ha llevado a cabo un estudio en forma de encuestas transversales, en el que se ha remitido por correo una encuesta anónima rellenada por los propios pacientes para conocer su opinión sobre la utilización y adecuación de los recursos médicos que utilizan.

\section{MÉTODOS}

\section{Pacientes}

La encuesta fue remitida a 393 pacientes diagnosticados de colitis ulcerosa o enfermedad de Crohn que se habían registrado en la Unitat d'Atenció Crohn-Colitis (UACC), independientemente del motivo de la consulta y del centro donde eran seguidos. Se han incluido todos aquellos pacientes que devolvieron la encuesta debidamente cumplimentada.

\section{Método}

La encuesta fue remitida por correo al domicilio de los participantes. Junto a la encuesta se facilitó un sobre franqueado para devolver la encuesta contestada a la UACC. La encuesta era anónima y estaba formada por 24 preguntas básicas referidas a datos sociodemográficos del paciente, generales de la enfermedad, quién les controla, cómo se programan las visitas, necesidad de atención urgente, valoración de la atención recibida, cómo creen que se puede mejorar su control, sugerencias para mejorar la atención, etc.

\section{Análisis estadístico}

Si los resultados obtenidos no pasan el test de normalidad de Kolmogorv-Smirnov, los resultados de las variables cuantitativas se expresaran como la mediana y percentiles 25-75. Las diferencias entre medianas se calcularán según el test de Mann-Whitney. Las diferencias entre proporciones se establecerán mediante el test de Fisher. Se han aceptado como significativos valores de $\mathrm{p}$ inferiores a 0,05 .

\section{RESULTADOS}

\section{Pacientes}

De los 393 pacientes a los que se remitió la encuesta, la devolvieron correctamente cumplimentada 237 $(60,3 \%)$, de los que 115 correspondieron a pacientes con enfermedad de Crohn y 122 a colitis ulcerosa. Las principales características clínicas de los pacientes incluidos se expresan en las tablas I y II. La edad fue similar para los grupos de pacientes con enfermedad de Crohn y colitis ulcerosa, observando un discreto predominio del género femenino en ambos grupos. Como era de esperar, la ma-

Tabla I. Principales características de los pacientes incluidos. Los resultados se indican en medianas (percentil 25-percentil 75)

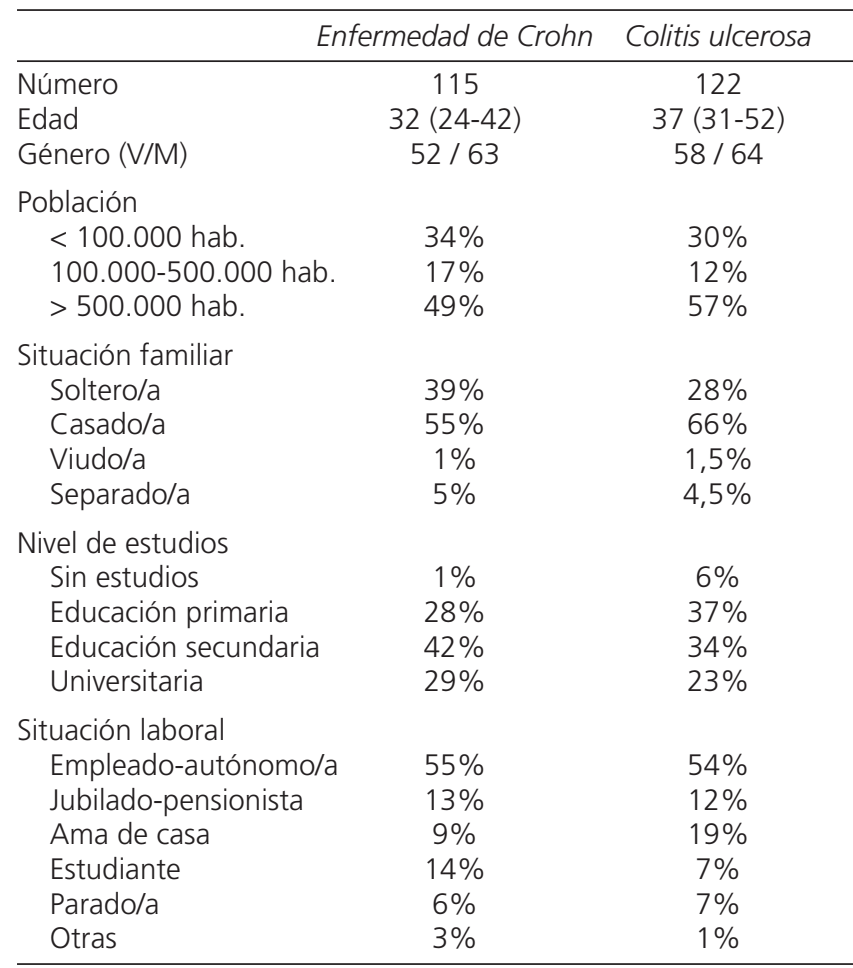


Tabla II. Principales características de la enfermedad de base de los pacientes incluidos. Los resultados se indican en medianas (percentil 25-percentil 75)

\begin{tabular}{lcc}
\hline & Enfermedad de Crohn & Colitis ulcerosa \\
\hline Número & 115 & 122 \\
Tiempo evolución (años) & $5(2-10)$ & $5(2-9)$ \\
Antecedente ingreso hospitalario & $81,8 \%$ & $57,3 \% *$ \\
Número ingresos hospitalarios & $2(1-4)$ & $1(0-2)^{*}$ \\
Antecedente intervención quirúrgica & $46,1 \%$ & $13,2^{*}$ \\
\hline
\end{tabular}

* $=p<0,05$

yoría de pacientes de ambos grupos viven en una gran ciudad. La situación familiar de los pacientes es también similar en ambos grupos, predominando los pacientes casados seguido de los solteros. Del mismo modo, el nivel de estudios es parecido entre ambos grupos de pacientes. La mayoría tiene la educación primaria o secundaria, destacando que alrededor de un cuarto de los pacientes son universitarios. La mayoría de pacientes de ambos grupos tienen una vida laboral activa, ya sea a cuenta de terceros o con trabajo autónomo. El 6\% de pacientes con enfermedad de Crohn y el 7\% con colitis ulcerosa están en situación de paro laboral, aunque desconocemos en cuántos casos es debido a la enfermedad.

\section{Atención sanitaria recibida}

El $94 \%$ de pacientes con enfermedad de Crohn y el $89 \%$ con colitis ulcerosa son controlados médicamente por un digestólogo hospitalario, mientras que sólo el 3 y $8 \%$ respectivamente son seguidos por el digestólogo del centro de atención primaria y el $3 \%$ de ambos grupos se definen controlados por su médico de cabecera. Probablemente el elevado número de pacientes controlados en un centro hospitalario sea un sesgo debido a que el reclutamiento de pacientes se ha llevado a cabo en un hospital terciario de referencia.

La mayor parte de las visitas se programan de una vez para la siguiente, sin relación con la actividad de la enfermedad, tanto en la enfermedad de Crohn $(93,1 \%)$ como en la colitis ulcerosa $(90,9 \%)$. El 6,1\% de pacientes con enfermedad de Crohn y el 8,2\% de aquellos con colitis ulcerosa son citados sólo cuando aparecen síntomas de la enfermedad.

Un problema que sufren con cierta frecuencia los pacientes con EII es el de requerir visitas médicas de forma urgente ya que, por la aparición de un brote o de complicaciones, requieren una adecuación del tratamiento. Aunque la mayoría de visitas se programan de forma rutinaria de una vez para otra, llama la atención que en el $75 \%$ de las ocasiones los cambios en el tratamiento se hace con poca demora ya sea porque los pacientes hacen consultas telefónicas, se reprograman las visitas de forma urgente o por automedicación (Tabla III). Llama la atención que al preguntar a los pacientes "cuántos días cree que suele
Tabla III. Demoras en los cambios de tratamiento cuando aparecen situaciones urgentes

\begin{tabular}{lcc}
\hline & Enfermedad de Crohn & Colitis ulcerosa \\
\hline Sin demora por consultar por teléfono & $50 \%$ & $39 \%$ \\
Sin demora por rapidez en la programación & $20 \%$ & $25 \%$ \\
Sin demora por automedicación & $8 \%$ & $11 \%$ \\
Con demora por retraso en la programación & $10 \%$ & $11 \%$ \\
No sabe, no contesta & $12 \%$ & $14 \%$ \\
\hline
\end{tabular}

transcurrir desde que se empieza a encontrar mal y su médico le prescribe el tratamiento" refieren sólo una mediana de $1(0-3,5)$ días en la enfermedad de Crohn y de 1 (0-5) día en la colitis ulcerosa.

Un número significativo de pacientes con EII tiene que acudir en algún momento a los servicios de urgencias hospitalarias. De hecho, el $85 \%$ de pacientes con enfermedad de Crohn y el 75\% de los afectos de colitis ulcerosa habían acudido alguna vez a un servicio de urgencias ( $\mathrm{p}=$ n.s. entre ambos grupos de pacientes). Los motivos aducidos por los pacientes para acudir a urgencias se indican en la tabla IV. Se preguntó a los pacientes si creen que se podría haber evitado ir a urgencias. La mayoría de pacientes (el 62\% de los afectos de enfermedad de Crohn y el 61\% del grupo colitis ulcerosa) consideran que no se podía haber evitado ir a urgencias. Sin embargo, el $20 \%$ de pacientes del grupo de enfermedad de Crohn y el $21 \%$ del grupo colitis ulcerosa refieren que podrían haber evitado ir a urgencias si hubieran tenido mayor información y mejor capacidad de autocontrol. En el mismo sentido, el $18 \%$ de pacientes con enfermedad de Crohn y con colitis ulcerosa consideran que hubieran podido evitar ir a urgencias si hubieran dispuesto de un servicio de atención telefónica.

Tabla IV. Motivos para acudir a los servicios de urgencias hospitalarias

\begin{tabular}{lcc}
\hline & Enfermedad de Crohn & Colitis ulcerosa \\
\hline Por la gravedad de un brote & $62 \%$ & $48 \%$ \\
Por no saber qué hacer & $14 \%$ & $19 \%$ \\
Por no tener otro recurso & $9 \%$ & $8 \%$ \\
No ha necesitado ir a urgencias & $15 \%$ & $25 \%$ \\
\hline
\end{tabular}

Los resultados obtenidos a la pregunta de si "cree que la atención sanitaria actual es la adecuada para el control de su enfermedad?" se indican en la tabla V. Cabe destacar que la mayoría de pacientes de ambos grupos señalan que el sistema asistencial actual cubre adecuadamente sus necesidades. De todos modos, una cantidad valorable de pacientes consideran que las demoras para la asistencia médica son excesivas, y un número inferior de pacientes que el tipo de asistencia no es el adecuado (Tabla V). 
Tabla V. Consideración de los pacientes acerca de si la atención sanitaria es la adecuada

\begin{tabular}{lcc}
\hline & Enfermedad de Crohn & Colitis ulcerosa \\
\hline Cubre perfectamente mis necesidades & $66 \%$ & $64 \%$ \\
No por su contenido & $7 \%$ & $11 \%$ \\
No por los tiempos de espera & $17 \%$ & $15 \%$ \\
No por la atención y las demoras & $4 \%$ & $6 \%$ \\
No sabe no contesta & $6 \%$ & $4 \%$ \\
\hline
\end{tabular}

Un aspecto que se quería determinar era si los pacientes consideran que la atención a su entorno más inmediato, como por ejemplo el entorno familiar, es necesaria para el control de su enfermedad. Cincuenta y dos pacientes (46\%) del grupo enfermedad de Crohn y 43 pacientes (36\%) del grupo colitis ulcerosa contestaron que la atención al entorno familiar es muy necesaria para ayudar al control de la enfermedad. Sólo 20 pacientes del grupo enfermedad de Crohn (17\%) y 36 pacientes del grupo colitis ulcerosa (30\%) consideran que la atención al entorno familiar no ayudan al control de la enfermedad. La diferente proporción de pacientes con enfermedad de Crohn o colitis ulcerosa que no consideran necesaria la atención al entorno familiar fue estadísticamente significativa $(\mathrm{p}<0,05)$.

\section{Información sobre la EII}

Se preguntó a los pacientes si consideraban que la información y el conocimiento acerca de su enfermedad era importante para el control de su salud. Los resultados se indican en la tabla VI, donde puede comprobarse que

Tabla VI. Consideración de los pacientes acerca del papel de la información y del conocimiento de la enfermedad en el control de la EII

\begin{tabular}{lcc}
\hline & Enfermedad de Crohn & Colitis ulcerosa \\
\hline ¿Considera importante estar bien & & \\
informado sobre la enfermedad? & & \\
Sí, es muy importante & $84 \%$ & $78 \%$ \\
Sí, ayudaría al control de la enfermedad & $14 \%$ & $19 \%$ \\
$\quad$ No en especial & $1 \%$ & $1 \%$ \\
$\quad$ No sabe no contesta & $1 \%$ & $2 \%$ \\
& & \\
¿Considera estar lo suficientemente & & \\
informado? & $37 \%$ & $39 \%$ \\
$\quad$ Sí, suficientemente & $49 \%$ & $44 \%$ \\
Sí, pero tengo muchas dudas & $13 \%$ & $16 \%$ \\
$\quad$ No lo suficiente & $1 \%$ & $1 \%$ \\
$\quad$ No sabe no contesta & & \\
& & \\
Si estuviera adecuadamente & & \\
informado, iniciaría el tratamiento & & $75 \%$ \\
de un brote antes de consultar? & $63 \%$ & $3 \%$ \\
$\quad$ Sí & $36 \%$ & \\
$\quad$ No & $1 \%$ & \\
$\quad$ No sabe no contesta & & \\
\hline
\end{tabular}

prácticamente todos los pacientes consideran importante tener una información adecuada o suficiente. Estos datos contrastan con el hecho que prácticamente la mitad de los pacientes se consideran bien informados pero con muchas dudas, y que el 13\% de los del grupo enfermedad de Crohn y el $16 \%$ del grupo colitis ulcerosa no se consideran bien informados (Tabla VI). Se preguntó si los pacientes consideraban que si estuvieran adecuadamente informados podrían empezar el tratamiento antes de consultar con su médico, para empezarlo lo antes posible en caso de síntomas de un brote de su enfermedad, a lo que respondieron afirmativamente la mayoría de pacientes en ambos grupos (Tabla VI).

Se analizó sobre qué aspectos de la EII no se consideraban bien informados y destaca que sólo 7 pacientes del grupo enfermedad de Crohn (6\%) y 8 del grupo colitis ulcerosa $(6 \%)$ no destacaron ninguna de las posibilidades que se daban a escoger, indicando que no había ninguna área de interés de la enfermedad sobre la que creyeran necesitar más información. Sin embargo, la mayoría de pacientes marcaron más de un área de interés sobre la que consideraban que necesitaban más información (Tabla VII).

Tabla VII. Número de pacientes que marcaron cada aspecto de la Ell sobre el que consideraban que no están suficientemente bien informados. La mayoría de pacientes marcaron más de un área de interés

\begin{tabular}{lcc}
\hline & Enfermedad de Crohn & Colitis ulcerosa \\
\hline Causas de la enfermedad & 65 & 80 \\
Cómo puede evolucionar la enfermedad & 60 & 62 \\
Complicaciones que se pueden presentar & 58 & 67 \\
Tratamiento de la enfermedad & 24 & 24 \\
Necesidad de intervención quirúrgica & 19 & 25 \\
Posibilidad de transmisión a los hijos o & & 22 \\
$\quad$ contagio & 36 & \\
\hline
\end{tabular}

\section{Sugerencias para mejorar la atención sanitaria}

En la encuesta remitida a los pacientes se dejó un espacio en blanco para que pudieran apuntar aquellas sugerencias que, según su opinión, pudieran contribuir a mejorar la asistencia sanitaria. Las sugerencias se pueden resumir en dar mayor información, agilizar la rapidez en la visitas o exploraciones, mejorar la accesibilidad a los servicios, crear programas de ayuda psicológica, facilitar dietas y disponer de dietistas, crear unidades de atención integral, que los médicos estén más informados, potenciar la investigación médica sobre la enfermedad y en sensibilizar a la sociedad a cerca del problema de la EII. 


\section{DISCUSIÓN}

Identificar las necesidades y conocer la opinión de los pacientes con enfermedades crónicas a cerca de la atención sanitaria que reciben, permite racionalizar los recursos y mejorar la atención que reciben. Por este motivo se remitió por correo una encuesta a 393 pacientes con enfermedad inflamatoria intestinal. Los pacientes se obtuvieron del registro de la Unitat d'Atenció Crohn-Colitis con la idea de obtener una tipología de paciente lo más variada posible. En este sentido participaron tanto pacientes con enfermedad de Crohn como colitis ulcerosa, varones y mujeres, etc. El tiempo de evolución de la enfermedad desde el diagnóstico es de 5 años, más de la mitad han necesitado algún ingreso hospitalario e incluso alguna intervención quirúrgica, el $46,1 \%$ de pacientes con enfermedad de Crohn y el 13,2\% con colitis ulcerosa. Ello da una idea de la severidad de la enfermedad y de que los pacientes han tenido experiencias en eventualmente todo tipo de recursos sanitarios. Sin embargo, en contra de la representatividad de la muestra escogida existe el hecho que la mayoría de pacientes eran controlados por médicos especialistas en centros hospitalarios de tercer nivel. Ello sugiere la posibilidad de un sesgo en la selección de la muestra, que tendría una menor representación de los pacientes con una enfermedad menos agresiva que siguen control exclusivo en centros de atención primaria.

La mayoría de pacientes programan sus visitas de forma rutinaria de una vez para la siguiente. Este sistema de consultas fijas puede tener el inconveniente de no ajustarse a las necesidades del paciente cuando surge la necesidad de una visita urgente por la aparición de un brote, complicaciones, etc. Sin embargo, dos terceras partes de los pacientes encuestados no refiere tener demoras en los cambios de medicación gracias a que pueden consultar por teléfono con su médico, porque pueden reprogramar las visitas con rapidez o simplemente porque se automedican. Posiblemente este resultado puede estar sesgado, en el sentido de que los pacientes incluidos tengan mayor facilidad para realizar consultas telefónicas al estar en contacto con la UACC, que facilita y promueve este tipo de atención. De todos modos, actualmente existe la tendencia a cambiar las programaciones fijas por programaciones telefónicas a demanda, lo que es preferido por los pacientes aunque a expensas de necesitar un sistema sanitario ágil para adaptarse a las necesidades urgentes de los pacientes $(11,12)$.

Cuando surge algún problema de salud que no puede ser solucionado en las consultas o dispensarios, los pacientes acuden a los servicios de urgencias hospitalarios. Esta situación no es infrecuente dado que el $85 \%$ de pacientes con enfermedad de Crohn y el 75\% de los afectos de colitis ulcerosa refieren haber acudido alguna vez a un servicio de urgencias hospitalario. Tan llamativo como la gran utilización del recurso de las urgencias hospitalarias son las ideas que indican los pacientes que podrían evitar su uso. Así, alrededor del $20 \%$ de los pacientes refieren que podrían evitar ir a urgencias si tuvieran mayor información, mejor capacidad de autocontrol o si hubieran dispuesto de un servicio de atención telefónica. Esta opinión refuerza la tendencia actual a la creación de unidades monográficas interactivas del tipo UACC en las que la consulta telefónica permite una atención médica continuada a medida de cada paciente, con reducción del número de visitas de presencia física (13).

En líneas generales, la mayoría de los pacientes refieren estar satisfechos con el tipo de atención sanitaria que reciben. Sin embargo, aspectos como las demoras en las citaciones o la atención al entorno más próximo al paciente, como es la familia, deberían mejorarse. En este sentido, la enfermedad inflamatoria intestinal tiene una repercusión que va más allá de la del propio paciente, y afecta también a los miembros de la familia que conviven con él influyendo en la dinámica familiar y afectando la calidad de vida de los familiares (3).

Los pacientes dan gran importancia al hecho de estar bien informados, pero un número significativo de pacientes consideran no estarlo suficientemente. Existen múltiples medios para difundir la información a los pacientes y familiares, desde la información en persona hasta mediante teléfono, internet, folletos, trípticos, vídeos, revistas, libros, asociaciones, etc. Informar a los pacientes es importante porque, como mínimo, se conoce que los pacientes que perciben estar poco informados refieren una peor calidad de vida (14) y porque la adquisición de conocimientos sobre la enfermedad se relaciona con una mejor adaptación emocional para vivir con la enfermedad inflamatoria intestinal (15). En cualquier caso, la información que se facilite a los pacientes debe darse con cuidado puesto que recientes observaciones sugieren que facilitar folletos informativos a pacientes ambulatorios causa, en los primeros días, un discreto deterioro de la calidad de vida (16). Sin embargo, cuando se ha preguntado a los pacientes sobre la utilidad de recibir folletos informativos, todos coinciden en considerarlo útil aunque a un tercio de los pacientes les cause ansiedad la información (17). De todos modos, la ansiedad que pueda provocar el acceso a la información mediante la administración de folletos a pacientes con enfermedad de Crohn va disminuyendo a largo plazo (18). Probablemente el mejor sistema para comunicar la información a pacientes y familiares sea la verbal en persona, pero esta puede complementarse o profundizarse mediante otros sistemas. Cuál puede ser más eficaz no parece estar aún bien establecido. La comparación de la eficacia en la adquisición de conocimientos relativos a la colonoscopia y el riesgo de cáncer en pacientes con colitis ulcerosa es la misma cuando se utilizan folletos o folletos y videos (19). De todos modos, la simple transmisión de conocimientos (información) debería complementarse con una adecuada utilización de los mismos (educación) para conseguir la adquisición de hábitos de vida saludables (promoción de la salud). 
Una fuente de información que está adquiriendo cada vez mayor importancia es Internet. Una reciente encuesta realizada a 173 pacientes de la Asociación Catalana de Enfermos con Crohn y Colitis (ACCU) ha puesto de manifiesto que el $84 \%$ de los pacientes estarían interesados en consultar una página web sobre la enfermedad inflamatoria intestinal, y que el $44 \%$ de los pacientes consultan en Internet temas referentes a su enfermedad (20). Estas evidencias sugieren que los pacientes con enfermedad inflamatoria intestinal tienen una buena predisposición para adquirir información y están dispuestos a recurrir a los recursos más modernos para conseguirla.

En conclusión, los pacientes con enfermedad inflamatoria intestinal tienen una opinión en general satisfactoria sobre la atención sanitaria que reciben. Sin embargo, se detectan carencias como la información insuficiente, el cuidado al entorno familiar y la accesibilidad-agilidad de los recursos sanitarios disponibles. La creación de unidades monográficas interactivas y las nuevas tecnologías telemáticas serán un recurso fundamental para mejorar la atención a los pacientes con enfermedad inflamatoria intestinal. 
